\title{
The Determinants of Firm Survival among Small Cluster Firms
}

\author{
Sana Ullah", Babur Wasim Arif ${ }^{* *}$, and Muhammad Tariq \\ Majeed $^{* * *}$
}

\begin{abstract}
This study analyzes the impact of education, experience, and social capital on firm survival using two waves of a survey conducted in 2008 and 2017 for the electrical fittings cluster based in Sargodha, Pakistan. Estimating a probit model, we find that the entrepreneur's education, experience, and social network are each positively correlated with firm survival. The interactions of education with both production and marketing experience are also significantly and positively related to firm survival while interactions of social capital with experience are not. Therefore, for the firms in this sector, education plays an important role directly as well as through production and marketing experience.
\end{abstract}

Keywords: Education, experience, social capital, firm survival, Pakistan.

JEL classification: J24, L26, L69.

\section{Introduction}

Small and medium-sized enterprises (SMEs), especially those in clusters, can be part of a strategy to support inclusive and sustainable industrial development in developing countries (Schmitz and Nadvi, 1999). However, the death rate among new firms in developing economies is very high: around 50 percent of all new manufacturing firms close down within the first 5 years, and only 20 percent survive longer than 10 years (Audretsch and Mahmood, 1995; and Ebert et al., 2018). McKenzie and Paffhausen (2017) report that small firms die at an average rate of 8.3 percent per year over the first 5 years in developing countries. Given this situation, firm survival has become an important research question in the developing country context (Cefis and Marsili, 2005; Box, 2008; Fontana and Nesta, 2010).

\footnotetext{
*School of Economics, Quaid-i-Azam University, Islamabad, Pakistan. Sana_ullah133@yahoo.com ** Assistant Professor, Department of Social Sciences, Iqra University, Islamabad, Pakistan. babur.wasim@iqraisb.edu.pk

**** Associate Professor, School of Economics, Quaid-i-Azam University, Islamabad, Pakistan. tariq@qau.edu.pk
} 
The empirical literature has shown firm performance to be correlated with both human capital and social capital (Santerelli and Tran, 2013). Human capital is not only based on education, but also comprises experience that a person attains by means of participation in work activities such as production and marketing. Education and experience, when combined, have been shown in the literature to be complements in firm performance (Iversen et al., 2016).

Our study collects data from the electrical fittings cluster in Sargodha, Pakistan to study firm survival. The two surveys, conducted in 2008 and 2017, contain data on the entry and survival of 232 enterprises formed within the electrical fittings cluster between 1967 and 2008. The econometric strategy employed is a probit regression, where we aim to investigate the effect of the interaction of education, experience, and social capital on firm survival in the cluster.

The rest of the paper is organized as follows: Section 2 offers a literature review. Section 3 reports on the dataset and its descriptive analysis. Section 4 discusses the model specification and results. Finally, conclusions are provided in last section.

\section{Literature review}

Human capital is made up of a variety of skills and knowledge accumulated through education, experience, and training (Unger et al, 2011). Mincer (1976) and Becker (1964) were pioneers of this concept in economics, and for decades human capital has been recognized as playing a critical role in entrepreneurial performance (Unger et al., 2011). Studies in this area have emphasized principally the entrepreneurs' human capital (Unger et al. 2011). The term human capital contains both specific as well as general human capital (Becker, 1993). Various studies have focused individually on both types - general and specific human capital - in entrepreneurship research (Bruderl et al., 1992; Gimeno et al, 1997; and Ucbasaran et al., 2008), and find both to have positive effects on firm performance.

Explicit knowledge is gained through education and tacit knowledge is gained through experience (Davidsson and Honig, 2003). Education is useful to entrepreneurs as it is an accumulation of explicit knowledge that may provide useful information, including the identification of new opportunities. Formal education produces general human capital (Davidsson and Honig, 2003), and while higher expenditures on formal education are expected to produce higher payoffs, non-linear effects have 
been observed empirically (Evans and Leighton, 1989; and Gimeno et al., 1997). In particular, a number of empirical studies have shown the positive effect of education on firm survival (Bates, 1990; Dahlqvist et al., 2000; and Block and Sandner, 2009).

Specific human capital might affect firm survival in the same way as general human capital. Prior experience plays a useful role in enterprise performance and helps in the accumulation of new knowledge (Weick, 1995). Bruderl et al (1992) used a sample of German firms to conclude that both types of human capital - education and experience of the founder have strong effects on the success of businesses. Experienced entrepreneurs are able to use their prior knowledge to ensure firm survival (see, e.g., Wilbon, 2002; Cantner et al., 2006), but also have greater ambitions for their firms in terms of intended venture size (Cassar, 2006).

From an entrepreneurial perspective, social capital provides entry into networks that facilitate the exchange of scarce resources (Greene and Brown, 1997; and Uzzi, 1999). During the innovation process, social capital assists in exposing the entrepreneur to new ideas and can help them in identifying new opportunities (Elfring and Hulsink, 2003), organizing and mobilizing resources (Stam et al., 2014), and building legitimacy for their firms (Elfring and Hulsink, 2003). Social capital also enhances the flow of information upon which entrepreneurs base decisions. Personal networks can also provide valuable resources in the form of formal and informal information and finance. Social capital gives an edge to survival in business, creating thickness in business ties that can help achieve that most fundamental goal, that is, of firm survival (Litzel, 2016). Family firms, internally dense with social capital, are also more likely to survive although their productivity growth is poorer (Morikawa, 2013).

Lastly, we consider the interaction between social and human capital as a driver of firm performance. Sonobe and Otsuka (2006) used case studies of East Asian firms to examine the joint influence of human and social capital on firm survival in clusters. Using the data for Vietnam entrepreneurs, Santarelli and Tran (2013) showed that factors related to human and social capital, individually as well as combined, have an influence on operating profit.

Table 1 is provides summary of firm survival literature related to human capital, social capital and firm characteristics including size and age. 
Table 1: Overview of firm survival literature

\begin{tabular}{|c|c|c|c|c|c|}
\hline Characteristic & Authors and year & Country & Industry & $\begin{array}{l}\text { Sample } \\
\text { size }\end{array}$ & $\begin{array}{c}\text { Relationship } \\
\text { with } \\
\text { survival? }\end{array}$ \\
\hline \multicolumn{2}{|c|}{ Human capital Wilbon (2002) } & USA & Mixed NC & 95 & Positive \\
\hline & Cantner et al. (2006) & Germany & Automobile C & 441 & Positive \\
\hline & Saridakis et al. (2008) & England & Mixed NC & 622 & Positive \\
\hline & $\begin{array}{l}\text { Wennberg and } \\
\text { Lindqvist (2008) }\end{array}$ & Swedish & Mixed C & 4397 & Positive \\
\hline \multirow[t]{3}{*}{ Social capital } & Watson (2007) & Australia & Mixed NC & 5027 & Positive \\
\hline & Morikawa (2013) & Japan & Mixed NC & 4466 & Positive \\
\hline & Litzel (2016) & Germany & Mixed NC & 88855 & Positive \\
\hline \multirow[t]{4}{*}{ Firm age } & $\begin{array}{l}\text { Cefis and Marsili } \\
\text { (2005) }\end{array}$ & Netherlands & Mixed NC & 3275 & Positive \\
\hline & $\begin{array}{l}\text { Alvarez and Vergara } \\
\text { (2013) }\end{array}$ & Chile & Mixed NC & 16752 & Positive \\
\hline & $\begin{array}{l}\text { Coad and Guenther } \\
\text { (2013) }\end{array}$ & Germany & $\begin{array}{l}\text { Machine } \\
\text { tool NC }\end{array}$ & 2000 & Positive \\
\hline & $\begin{array}{l}\text { Esteve-Pérez et } \\
\text { al.(2017) }\end{array}$ & Spanish & Mixed NC & 4546 & Positive \\
\hline \multirow[t]{5}{*}{ Firm size } & $\begin{array}{l}\text { Fotopoulos and Louri } \\
(2000)\end{array}$ & Greek & Mixed NC & 1115 & Positive \\
\hline & Box (2008) & Sweden & Mixed NC & 2200 & Positive \\
\hline & Strotmann (2007) & Germany & Mixed NC & 2605 & Positive \\
\hline & Audretsch et al. (2016) & China & Mixed NC & 3000 & Positive \\
\hline & Huggins et al. (2017) & U.K & Mixed NC & 3251 & Positive \\
\hline
\end{tabular}

Notes: C stand for cluster and NC stand for non-cluster industry.

\section{Data overview and descriptive analysis}

Sargodha is located in the Punjab province of Pakistan and it is interconnected with other well-established centers of industrial clusters such as Faisalabad, Gujarat, Gujranwala, and Sialkot, which are famous for textiles, plastic products, metal products, sports goods, light machinery and surgical instruments. Sargodha in particular has become known as a cluster where a large number of SMEs produce electrical fittings. Therefore, primary data was collected from the electrical fittings cluster based there. The first wave of the survey was conducted by Arif and Sonobe (2012) in 2008. The second wave of the survey has been conducted in 2017. The data collection method consisted of personal interviews of the executive officer or firm owner of the enterprises and subcontractor workshops. The major difficulty encountered in conducting the survey was the listing exercise of the census of enterprises, since the Sargodha regional 
offices of the Small and Medium Enterprises Development Authority (SMEDA) and Pakistan Bureau of Statistics (PBS) did not have a reliable list of electrical fittings firms.

According to the list of SMEs provided by the Arif and Sonobe (2012), 126 enterprises worked as manufacturers and 106 as subcontractors, to comprise a total sample of 232 firms surveyed from the cluster. We revisited the same enterprises during 2017, and found 92 enterprises had been closed down while 140 firms survived in the industry.

The entrepreneurs of Sargodha's electrical fittings cluster have a moderate level education but are rich in prior production experience. The cluster is characterized by similar social backgrounds and the majority of entrepreneurs come from the local area's majority ethnic group. There are also strong family networks within the cluster. Interestingly, secondgeneration entrepreneurs have moved into trading, marketing, and other related activities of the electrical fittings cluster.

Table 2: Descriptive statistics

\begin{tabular}{lccccc}
\hline Variable & Obs & Mean & Std. Dev. & Min & Max \\
\hline Firm survival & 232 & 0.603 & 0.490 & 0 & 1 \\
Owner education & 232 & 7.68 & 3.864 & 0 & 16 \\
Production experience & 232 & 0.685 & 0.465 & 0 & 1 \\
Marketing experience & 232 & 0.125 & 0.159 & 0 & 1 \\
& & & & & \\
Friends and relatives in same industry & 232 & 2.125 & 4.784 & 0 & 35 \\
Parents in same business & 232 & 0.039 & 0.194 & 0 & 1 \\
Birth place in Sargodha & 232 & 0.879 & 0.326 & 0 & 1 \\
Ethnic majority & 232 & 0.272 & 0.446 & 0 & 1 \\
& & & & & \\
Owner age & 232 & 40.03 & 9.90 & 22 & 70 \\
Firm size & 232 & 10.31 & 16.54 & 1 & 216 \\
cohort ${ }_{\text {upto } 1980}$ & 232 & 0.039 & 0.194 & 0 & 1 \\
cohort ${ }_{1981-1990}$ & 232 & 0.133 & 0.340 & 0 & 1 \\
cohort ${ }_{\text {1991-2000 }}^{232}$ & 0.297 & 0.458 & 0 & 1 \\
cohort $2001-2008$ & 232 & 0.530 & 0.500 & 0 & 1 \\
\hline
\end{tabular}

Table 2 provides descriptive statistics for all firms. Firm survival will be the outcome of interest in the econometric model. About 60 percent of firms survived from 2008 until 2017 in the cluster. The average level of owner education is 7.86 years. In particular, 69 percent of the owners have prior production experience, while 13 percent have marketing experience. 
Each entrepreneur has, on average, 2 friends and relatives (FRs) in the same industry. Therefore, social capital is strong in the cluster. We found that 88 percent of entrepreneurs were born in Sargodha. But only 4 percent of the entrepreneurs have parents in the same business. The mean entrepreneur age for the sample is about 40 years. Firm sizes ranges from 1 to 216 with an average of 10.31 employees. Table 1 also reports the four birth cohorts of the sample firms over the study period. The first cohort, who entered between 1960 and 1980 comprise only 3 percent of firms surveyed. 13 percent of the firms come from the second entry cohort. Similarly, 29 percent of sample firms had entered as part of the third cohort, while the remaining 53 percent entered in a year between 2001 and 2008.

Table 3 shows the main difference between surviving and exiting firms. Firms that survived from 2008 until 2017 tended to have more marketing experience and their owners had more education, while exiting firms were more reliant on production experience. Similarly, surviving firms display higher levels of social capital and larger firm sizes than those that had exited by 2017.

Table 3: Characteristics of surviving firms and exiting firms, 2008-2017

\begin{tabular}{lcc}
\hline & Surviving firms & Exiting firms \\
\hline Number of Firms & $\mathbf{1 4 0}$ & $\mathbf{9 2}$ \\
Percentage of Firms (\%) & $\mathbf{6 0 . 3 4}$ & $\mathbf{3 9 . 6 6}$ \\
\hline Owner education & 8.26 & 6.82 \\
Production experience & 0.66 & 0.71 \\
Marketing experience & 0.18 & 0.13 \\
& & \\
FRs in same industry & 2.49 & 1.58 \\
Parents in same business & 0.03 & 0.04 \\
Birth place in Sargodha & 0.90 & 0.85 \\
Ethnic majority & 0.26 & 0.19 \\
& & \\
Owner age & 40.03 & 40.02 \\
Firm size & 12.13 & 7.54 \\
cohort ${ }_{\text {up to } 1980}$ & 0.06 & 0.01 \\
cohort ${ }_{1981-1990}$ & 0.14 & 0.12 \\
cohort ${ }_{1991-2000}$ & 0.34 & 0.27 \\
cohort ${ }_{\text {2001-2008 }}$ & 0.51 & 0.54 \\
\hline
\end{tabular}

Source: Authors' calculations based on primary data. 


\section{Model specification and estimation results}

The model we have adopted to estimate the determinants of firm survival includes conventional factors (education and experience) in addition to newer factors like the role of social networks. The main purpose of our study is to empirically examine how education, experience, and social capital relate individually to firm survival as well as if there are any interaction effects between these factors.

We start with the base econometric model specification in equation 1 which exhibits the separate effects of education, experience, and social networks on firm survival.

$$
F S_{i}=\beta_{0}+\beta_{1} E d u_{i}+\beta_{2} E x p_{i}+\beta_{3} S c_{i}+\beta_{i} Z_{i}+\epsilon_{i}
$$

where FS represents firm survival, $E d u$ is the firm owner's education level, Exp is for prior production and marketing experience, Sc is social network, and $Z$ is vector of control variables which include owner age, firm size and cohort dummy variables, and $\epsilon_{i}$ represents robust error term, and $i$ denotes firms. FS equals 1 if firms survived between 2008 and 2017, and 0 otherwise. On the right hand side, we have three categories of variables: human capital (education, production experience, and marketing experience), social capital (prior number of FRs in same industry, ethnic majority, father is same industry, and birth place in Sargodha), and control variables (owner age, firm size, and dummies of cohort variables). These variables are either dummy or count in nature. Given the binary nature of the dependent variable, $F S$, the regression is run with the probit model.

Next, we incorporate interaction terms into the model since the probability of firm survival may be boosted when education is complemented with experience and social capital. Therefore these additional interactions terms are added in the model in equation 2: $E d u \times E x p, E d u \times S c$, and $E x p \times S c$, respectively. We represent these interactions in the following probit regression model:

$$
\begin{aligned}
F S_{i}= & \beta_{0}+\beta_{1} E d u_{i}+\beta_{2} \operatorname{Exp}_{i}+\beta_{3} S c_{i}+\beta_{4} E d u \times \operatorname{Exp}_{i}+\beta_{5} E d u \times S c_{i}+ \\
& \beta_{6} \operatorname{Exp} \times S c_{i}+\beta_{i} Z_{i}+\epsilon_{i}
\end{aligned}
$$

Table 4 presents our results for firm survival, estimating equations 1 and 2 using a probit model. The entrepreneur's education is positively and significantly related to firm survival in all specifications. Both prior 
production experience and prior marketing experience are also positively and significantly correlated with firm survival. This implies that entrepreneurs with backgrounds in either production or marketing are more likely to survive. Overall, only one of the social capital variables is statistically significant in relation to firm survival, which is the number of friends and relatives in the same industry. It should be noted that the results described here are correlations and should not be interpreted causally, since important unobserved variables, including entrepreneurial ability and intelligence, would be positively correlated with both observed education, experience, and firm performance. 
Table 4: Determinants of Firm Survival

\begin{tabular}{|c|c|c|c|c|c|c|}
\hline Variables & (1) & (2) & (3) & (4) & (5) & (6) \\
\hline Owner education & $\begin{array}{l}0.049^{* *} \\
(0.025)\end{array}$ & $\begin{array}{l}0.053^{* *} \\
(0.025)\end{array}$ & $\begin{array}{c}0.0528^{* *} \\
(0.025)\end{array}$ & $\begin{array}{c}0.0574^{* *} \\
(0.026)\end{array}$ & $\begin{array}{c}0.0492^{* *} \\
(0.025)\end{array}$ & $\begin{array}{c}0.0503^{* *} \\
(0.025)\end{array}$ \\
\hline Production experience & $\begin{array}{l}0.427^{* *} \\
(0.208)\end{array}$ & $\begin{array}{l}0.522^{*} \\
(0.301)\end{array}$ & $\begin{array}{l}0.423^{* *} \\
(0.210)\end{array}$ & $\begin{array}{l}0.431^{* *} \\
(0.209)\end{array}$ & $\begin{array}{l}0.446^{*} \\
(0.243)\end{array}$ & $\begin{array}{l}0.423^{* *} \\
(0.209)\end{array}$ \\
\hline Marketing experience & $\begin{array}{l}0.889^{*} \\
(0.533)\end{array}$ & $\begin{array}{l}0.988^{*} \\
(0.516)\end{array}$ & $\begin{array}{c}2.482^{* * *} \\
(0.771)\end{array}$ & $\begin{array}{l}0.895^{*} \\
(0.543)\end{array}$ & $\begin{array}{l}0.888^{*} \\
(0.523)\end{array}$ & $\begin{array}{l}1.068^{*} \\
(0.553)\end{array}$ \\
\hline FRs in same industry & $\begin{array}{l}0.047^{* *} \\
(0.022)\end{array}$ & $\begin{array}{l}0.045^{*} \\
(0.024)\end{array}$ & $\begin{array}{l}0.041^{*} \\
(0.022)\end{array}$ & $\begin{array}{l}0.092^{* *} \\
(0.044)\end{array}$ & $\begin{array}{l}0.070^{* *} \\
(0.034)\end{array}$ & $\begin{array}{l}0.042^{* *} \\
(0.021)\end{array}$ \\
\hline Parents in same business & $\begin{array}{c}-0.202 \\
(0.460)\end{array}$ & $\begin{array}{l}-0.140 \\
(0.497)\end{array}$ & $\begin{array}{l}-0.209 \\
(0.463)\end{array}$ & $\begin{array}{l}-0.190 \\
(0.462)\end{array}$ & $\begin{array}{c}-0.242 \\
(0.471)\end{array}$ & $\begin{array}{l}-0.208 \\
(0.462)\end{array}$ \\
\hline Birth place in Sargodha & $\begin{array}{l}-0.0512 \\
(0.264)\end{array}$ & $\begin{array}{l}-0.076 \\
(0.265)\end{array}$ & $\begin{array}{l}-0.062 \\
(0.265)\end{array}$ & $\begin{array}{l}-0.044 \\
(0.265)\end{array}$ & $\begin{array}{l}-0.049 \\
(0.265)\end{array}$ & $\begin{array}{l}-0.067 \\
(0.268)\end{array}$ \\
\hline Ethnic majority & $\begin{array}{l}-0.139 \\
(0.201)\end{array}$ & $\begin{array}{l}-0.193 \\
(0.204)\end{array}$ & $\begin{array}{l}-0.130 \\
(0.201)\end{array}$ & $\begin{array}{c}-0.161 \\
(0.202)\end{array}$ & $\begin{array}{l}-0.139 \\
(0.201)\end{array}$ & $\begin{array}{l}-0.130 \\
(0.203)\end{array}$ \\
\hline $\begin{array}{l}\text { Owner education } \times \text { production } \\
\text { experience }\end{array}$ & & $\begin{array}{l}0.112^{* *} \\
(0.053)\end{array}$ & & & & \\
\hline $\begin{array}{l}\text { Owner education } \times \text { marketing } \\
\text { experience }\end{array}$ & & & $\begin{array}{l}0.204^{* *} \\
(0.084)\end{array}$ & & & \\
\hline $\begin{array}{l}\text { Owner education } \times \text { FRs in same } \\
\text { industry }\end{array}$ & & & & $\begin{array}{c}0.006 \\
(0.005)\end{array}$ & & \\
\hline $\begin{array}{l}\text { Production experience } \times \text { FRs in } \\
\text { same industry }\end{array}$ & & & & & $\begin{array}{c}0.086 \\
(0.061)\end{array}$ & \\
\hline $\begin{array}{l}\text { Marketing experience } \times \text { FRs in } \\
\text { same industry }\end{array}$ & & & & & & $\begin{array}{c}0.261 \\
(0.232)\end{array}$ \\
\hline Owner age & $\begin{array}{l}0.0014 \\
(0.010)\end{array}$ & $\begin{array}{c}0.013 \\
(0.011)\end{array}$ & $\begin{array}{c}0.012 \\
(0.011)\end{array}$ & $\begin{array}{c}0.012 \\
(0.011)\end{array}$ & $\begin{array}{c}0.012 \\
(0.011)\end{array}$ & $\begin{array}{c}0.013 \\
(0.011)\end{array}$ \\
\hline Firm size & $\begin{array}{l}0.0295^{* * *} \\
(0.011)\end{array}$ & $\begin{array}{c}0.0296^{* * *} \\
(0.011)\end{array}$ & $\begin{array}{l}0.0296^{* * *} \\
(0.011)\end{array}$ & $\begin{array}{l}0.0292^{* *} \\
(0.012)\end{array}$ & $\begin{array}{l}0.0251^{* *} \\
(0.012)\end{array}$ & $\begin{array}{l}0.0290^{* * *} \\
(0.011)\end{array}$ \\
\hline Cohort ${ }_{1981-1990}$ & $\begin{array}{l}1.088^{*} \\
(0.558)\end{array}$ & $\begin{array}{l}1.127^{* *} \\
(0.538)\end{array}$ & $\begin{array}{l}1.116^{* *} \\
(0.559)\end{array}$ & $\begin{array}{l}1.068^{*} \\
(0.562)\end{array}$ & $\begin{array}{l}1.101^{* *} \\
(0.560)\end{array}$ & $\begin{array}{l}1.097^{* *} \\
(0.558)\end{array}$ \\
\hline cohort $1991-2000$ & $\begin{array}{l}1.043^{*} \\
(0.537)\end{array}$ & $\begin{array}{l}1.074^{* *} \\
(0.520)\end{array}$ & $\begin{array}{l}1.049^{*} \\
(0.536)\end{array}$ & $\begin{array}{l}1.020^{*} \\
(0.538)\end{array}$ & $\begin{array}{l}1.060^{* *} \\
(0.540)\end{array}$ & $\begin{array}{l}1.041^{*} \\
(0.536)\end{array}$ \\
\hline cohort 2001-2008 & $\begin{array}{l}-0.897^{*} \\
(0.540)\end{array}$ & $\begin{array}{l}-0.896^{*} \\
(0.523)\end{array}$ & $\begin{array}{l}-0.896^{*} \\
(0.510)\end{array}$ & $\begin{array}{l}-0.924^{*} \\
(0.544)\end{array}$ & $\begin{array}{l}-0.941^{*} \\
(0.543)\end{array}$ & $\begin{array}{l}-0.892^{*} \\
(0.520)\end{array}$ \\
\hline Constant & $\begin{array}{c}0.461 \\
(0.893)\end{array}$ & $\begin{array}{l}1.339 \\
(0.975)\end{array}$ & $\begin{array}{c}0.493 \\
(0.894)\end{array}$ & $\begin{array}{c}0.340 \\
(0.910)\end{array}$ & $\begin{array}{c}0.604 \\
(0.910)\end{array}$ & $\begin{array}{c}0.488 \\
(0.896)\end{array}$ \\
\hline Pseudo R ${ }^{2}$ & 0.167 & 0.182 & 0.172 & 0.170 & 0.174 & 0.168 \\
\hline Observations & 232 & 232 & 232 & 232 & 232 & 232 \\
\hline
\end{tabular}

Notes: The dependent variable is firm survival and results are taken from a probit regression. Heteroskedasticity robust standard errors are in parentheses. Significance of coefficients at the $10 \%, 5 \%$, and $1 \%$ levels are shown by ${ }^{*} * *$, and $* * *$, respectively 
In columns (2) through (6), interactions between education, experience and social network variables are also included, one by one. The interaction of both types of experience with education are positive and significantly related to survival, while at same time the significance of the individual effects (education and experience) are maintained. These findings suggest that not only are business experience and education individually important but that experience is enhanced by the entrepreneur's education in relation to the survival probability of firms. On the other hand, while the effects of social capital interacted with education and experience have the expected (positive) direction, they were not statistically significant.

The results also show a positive relationship between the firm size and the survival probability. This finding is also supported by earlier results that have claimed that survival rate of large firms is more as compared to small firms (Fotopoulos and Louri, 2000; and Audretsch et al., 2016). It may be the case that larger firms are more able to weather economic instability and survive, but this result cannot in general be interpreted as a causal relationship. Firm size is likely to be correlated with unobserved firm characteristics, especially total factor productivity, that increase both firm size and chances of survival.

The analysis also included birth cohort dummies in the estimation. In general, the youngest cohort of firms, founded since 2000, were the least likely to survive and the firms in the second and third cohorts were more likely to survive between 2008 and 2017 in comparison to the first (oldest) cohort, although the latter represented only a very small number of firms, making it difficult to generalize. While it is tempting to suggest that older firms are more likely to survive due to the depth of their experience, these results cannot typically be interpreted in this way since the sample analyzed here is a selected one: the majority of firms founded in those earlier periods had already exited, and only the most productive firms from the older cohorts would have survived until 2008 in order to be included in the sample. Because they are more productive (and not because they are older), older firms are more likely to survive until 2017 as well.

\section{Conclusions}

Small, young firms in Pakistan, as in most countries, face difficulties in survival, even in in clusters, which are supposed to be amenable to industrial development. Therefore, our study aimed to understand the characteristics of firms that do survive in this context. For 
this purpose, we employed a unique dataset from Sargodha's electrical fittings cluster collected in 2008 and 2017. Using a probit model, the results revealed that higher levels of both types of human capital, that is, education and experience, as well as the size of an entrepreneurs' social network were indicators of a higher likelihood of firm survival. We found additional gains to firm survival probabilities when education was interacted with either marketing or production experience.

These findings are in line with the modern emerging literature on industrial clusters in East Asia, South Asia, and Africa (Sonobe and Otsuka, 2006) which suggests that more formally educated and experienced entrepreneurs have positive influence on enterprises' development. The results reveal that education, production, and marketing experience individually as well as jointly have increased the life expectancy of the firm. The empirical literature also suggests that social capital is helpful in survival and our empirical findings suggest the same. 


\section{References}

Arif, B. W., \& Sonobe, T. (2012). Virtual Incubation in Industrial Clusters: A Case Study in Pakistan. Journal of Development Studies, 48(3), 377-392.

Audretsch, D. B., \& Mahmood, T. (1995). New Firm Survival: New Results Using a Hazard Function. The Review of Economics and Statistics, 77(1), 97-112.

Audretsch, D., Guo, X., Hepfer, A., Menendez, H., \& Xiao, X. (2016). Ownership, productivity and firm survival in China. Economia $e$ Politica Industriale, 43(1), 67-83.

Bates, T. (1990). Entrepreneur Human Capital Inputs and Small Business Longevity. The Review of Economics and Statistics, 72(4), 551-565.

Becker, G. S. (1993). Human Capital. Chicago press.

Block, J., \& Sandner, P. (2009). Necessity and Opportunity Entrepreneurs and Their Duration in Self-employment: Evidence from German Micro Data. Journal of Industry, Competition and Trade, 9(2), 117-137.

Box, M. (2008). The death of firms: exploring the effects of environment and birth cohort on firm survival in Sweden. Small Business Economics, 31(4), 379-393.

Bruderl, J., Preisendorfer, P., \& Ziegler, R. (1992). Survival Chances of Newly Founded Business Organizations. American Sociological Review, 57(2), 227-239.

Cantner, U., Dreßler, K., \& Krüger, J. J. (2006). Firm survival in the German automobile industry. Empirica, 33(1), 49-60.

Cassar, G. (2006). Entrepreneur opportunity costs and intended venture growth. Journal of Business Venturing, 21(5), 610-632.

Cefis, E., \& Marsili, O. (2005). Survivor: The role of innovation in firms' survival. Research Policy, 35(5), 626-641.

Coad, A., \& Guenther, C. (2013). Diversification patterns and survival as firms mature. Small Business Economics, 41(3), 633-649. 
Cooper, A. C., Gimeno-Gascon, F., \& Woo, C. Y. (1994). Initial human and financial capital as predictors of new venture performance. Journal of Business Venturing, 9(5), 371-395.

Dahlqvist, J., Davidsson, P., \& Wiklund, J. (2000). Initial Conditions as Predictors of New Venture Performance: A Replication and Extension of the Cooper et al. study. Enterprise and Innovation Management Studies, 1(1), 1-17.

Davidsson, P., \& Honig, B. (2003). The role of social and human capital among nascent entrepreneurs. Journal of Business Venturing, 18(3), 301-331.

Ebert, T., Brenner, T. \& Brixy, U. (2019). New firm survival: the interdependence between regional externalities and innovativeness. Small Business Economics, 53, 287-309.

Elfring, T., \& Hulsink, W. (2003). Networks in Entrepreneurship: The Case of High-technology Firms. Small Business Economics, 21(4), 409-422.

Esteve-Pérez, S., \& Rodríguez, D. (2017). The dynamics of exports and R\&D in SMEs. Small Business Economics, 41(1), 219-240.

Evans, D. S., \& Leighton, L. S. (1989). Some Empirical Aspects of Entrepreneurship. The Economics of Small Firms, 79-99.

Fotopoulos, G., \& Louri, H. (2004). Firm Growth and FDI: Are Multinationals Stimulating Local Industrial Development? Journal of Industry, Competition and Trade, 4(3), 163-189.

Gimeno, J., Folta, T. B., Cooper, A. C., \& Woo, C. Y. (1997). Survival of the Fittest? Entrepreneurial Human Capital and the Persistence of Underperforming Firms. Administrative Science Quarterly, 42(4), 750-774.

Greene, P. G., \& Brown, T. E. (1997). Resource needs and the dynamic capitalism typology. Journal of Business Venturing, 12(3), 161-173.

Iversen, J., Malchow-Møller, N., \& Sørensen, A. (2016). Success in entrepreneurship: a complementarity between schooling and wage-work experience. Small Business Economics, 47(2), 437-460. 
Litzel, N. (2016). Does embeddedness in clusters enhance firm survival and growth? An establishment-level analysis using CORIS data. Regional Studies, 51(4), 563-574.

McKenzie, D. J., \& Paffhausen, A. L. (2017). Small Firm Death in Developing Countries. Policy Research Working Papers.

Morikawa, M. (2013). Productivity and survival of family firms in Japan. Journal of Economics and Business, 70, 111-125.

Santarelli, E., \& Tran, H. T. (2012). The interplay of human and social capital in shaping entrepreneurial performance: the case of Vietnam. Small Business Economics, 40(2), 435-458.

Schmitz, H., \& Nadvi, K. (1999). Clustering and Industrialization: Introduction. World Development, 27(9), 1503-1514.

Sonobe T, and Otsuka K (2006). Cluster-based industrial development: an East Asian model. Palgrave Macmillan, New York.

Stam, W., Arzlanian, S., \& Elfring, T. (2014). Social capital of entrepreneurs and small firm performance: A meta-analysis of contextual and methodological moderators. Journal of Business Venturing, 29(1), 152-173.

Strotmann, H. (2007). Entrepreneurial Survival. Small Business Economics, 28(1), 87-104. Thurow, L. C., \& Mincer, J. (1976). Schooling, Experience, and Earnings. Industrial and Labor Relations Review, 29(3), 454-472.

Ucbasaran, D., Westhead, P., \& Wright, M. (2008). Opportunity Identification and Pursuit: Does an Entrepreneur's Human Capital Matter? Small Business Economics, 30(2), 153-173.

Unger, J. M., Rauch, A., Frese, M., \& Rosenbusch, N. (2011). Human capital and entrepreneurial success: A meta-analytical review. Journal of Business Venturing, 26(3), 341-358.

Uzzi, B. (1999). Embeddedness in the Making of Financial Capital: How Social Relations and Networks Benefit Firms Seeking Financing. American Sociological Review, 64(4), 481-492. 
Van Der Sluis, J., Van Praag, M., \& Vijverberg, W. (2008). Education and entrepreneurship selection and performance: a review of the empirical literature. Journal of Economic Surveys, 22(5), 795-841.

Weick, K. E. (1995). Sensemaking in organizations. Thousand Oaks, CA: Sage.

Wennberg, K., \& Lindqvist, G. (2008). The effect of clusters on the survival and performance of new firms. Small Business Economics, 34(3), 221241.

Wilbon, A. D. (2002). Predicting survival of high-technology initial public offering firms. The Journal of High Technology Management Research, 13(1), 127-141. 